\title{
Effect of conservation methods on the mineral contents of some maize varieties (Zea mays L.) produced in Côte d'Ivoire
}

\author{
Deffan Kahndo Prudence ${ }^{1 *}$, Nemlin Gnopo Jean², Akanvou Louise², Deffan Zranseu Ange Benedicte², \\ Kouamé Patrice ${ }^{1}$ \\ ${ }_{1}^{1}$ Department of Food Science and Technology, University of Nangui-Abrogoua, 02 PO Box 801 Abidjan 02, Côte d'Ivoire \\ ${ }^{2}$ Laboratory of Technological Research Station, National Center of Agronomic Research, 08 BP 881 Abidjan 08, Côte \\ d'Ivoire \\ "Author of correspondence: 08 BP 881 Abidjan 08, Côte d'Ivoire, E-mail: pdeffan@yahoo.fr
}

Original submitted in on $18^{\text {th }}$ September 2015. Published online at www.m.elewa.org on $31^{\text {st }}$ October 2015 http://dx.doi.org/10.4314/jab.v94i1.7

\begin{abstract}
Objective: The aim of this study was to evaluate the effect of conservation methods on the mineral content of some maize varieties during post-harvest storage. To meet the needs for the human and animal consumption, it is necessary to determine the mineral contents of raw materials.

Methodology: Eight maize varieties, including two local varieties used as controls ("Violet de Katiola" and AC176) and six improved varieties (Obatanpa, MDJ, EV8728, GMRP18, Acr97TZLcomp-1w and Acr97TZLcomp-1wsynth), produced by the Centre National de Recherché Agronomique (CNRA), were stored according to three preservation methods (granary, attic and jute bag) during 120 days. Sampling was performed every 30 days, followed by chemical analyses.

Results: The ash contents of local varieties were better preserved in the granary than in the attic or the jute bag because no significant variation was observed at the end of the preservation time. In improved varieties, all the ash contents varied. Concerning constitutive minerals, magnesium and calcium contents were preserved in all varieties respectively during 30 and 120 days of storage in the granary, the attic and the jute bag. On the other hand, some variations were observed for potassium and phosphorus contents. For example, "Violet de Katiola" potassium content was best preserved in the jute bag during 120 days; AC176 and EV 8728 potassium contents were best preserved in the attic respectively during 90 days and 60 days. The three preservation modes were suitable to maintain ACr97 comp1wsynth potassium content between 60 and 120 days; but in this variety, phosphorus was best preserved in the attic during 90 days.

Conclusion: The three modes of maize grain storage were suitable to preserve magnesium and calcium contents of local and improved varieties and Acr97TZLcomp1-wsynth potassium content.

Keywords: Maize, variety, mineral content, preservation, period, Côte d'Ivoire.
\end{abstract}




\section{INTRODUCTION}

Cereals, including sorghum, millet, wheat, rice, barley, and maize, are important basic foodstuffs in Asia and Africa tropical semi-arid regions. They remain the main energy sources for millions of inhabitants among the poorest of these regions. Cereals and their derivatives play important nutritional, social and economic roles. They provide about two-thirds of energy needs and on an average $70 \%$ of the protein content in a diet (Bartali et al. 1994). At the global level, two-thirds of maize products are used for animal feed and $27 \%$ for human consumption. In Africa, $50 \%$ of the population depends on maize, which is an important source of proteins, vitamins and minerals. It is consumed either as whole seeds (separate or on cob), is reduced to flour and prepared in the form of gruel or baked cake. The whole maize plant can be consumed by livestock as fresh or dried forage or as silage. This plant fattens beef cattle more quickly and thus increases the production of milk in dairy cows. In Côte d'Ivoire, maize (Zea Mays L.) is the second cereal after rice in terms of production and consumption. Maize is grown in all agro-ecological zones and is used in human and animal consumption and as raw material in the industries. Annual production estimated at 700000 tons, is fully consumed, and remains insufficient to meet

\section{MATERIALS AND METHODS}

Raw materials: In this study, raw materials were six improved maize varieties (Obatanpa; GMRP-18; EV8728; MDJ; ACR97 comp1w; ACR97 comp1w synth) and two population needs (Akanvou et al., 2007). Cultivated in all agro-ecological zones, maize is consumed countrywide in various forms. For poorest populations, products resulting from maize processing constitute the most important elements of their food staple. The reserves of maize permit too many populations to survive when the harvest of other cereals (millet, wheat, rice) is bad. A good conservation of maize grains is thus necessary for the safeguarding of stocks in appropriate quantity and quality. The importance of maize is due to its availability all the year long (IITA, 2012). Because of its economic assets (easy to produce, collect and stock) and nutritive value (high starch, protein and mineral contents), maize is a competitive product that contributes to lowering the prices of food commodities such as milk and meat (Nuss et Tanumihardjo, 2011). Minerals are essential for any living organism. Their deficiency in the body can lead to many troubles of physiological functions. Minerals derived from raw materials native content, from food additives and water (Schlegel et al., 2009). Thus, in order to use them in an optimal way, according to the needs for the human and animal consumption, their content must be known during the preservation of the maize varieties cultivated in Côte d'Ivoire. This work has been implemented in this context.

local varieties used as controls (AC176; violet de Katiola) (Table 1).

Table 1: Characteristics of the eight maize varieties

\begin{tabular}{l|c|c|c|c}
\hline VARIETIES & TYPE & COLOR & TEXTURE & ORIGIN \\
\hline Violet de Katiola & local & violet & horn & Katiola \\
\hline AC 176 & local & yellow & horn & Bouaké \\
\hline Obatanpa & improved & with & dente & IITA \\
\hline MDJ & improved & yellow & horn & CNRA \\
\hline EV 87 28 & improved & yellow & semi-dente & CNRA \\
\hline GMRP 18 & improved & yellow & horn & CNRA \\
\hline Acr 97TZL comp 1-W & improved & with & horn-dente & IITA \\
\hline Acr 97TZL comp 1-W synth & improved & with & horn & IITA \\
\hline
\end{tabular}

Sample preparation: The eight maize varieties were harvested from Katiola, Bouake, Ferké and from CNRA maize collection, and then regenerated on an experimental plot at CNRAAnguededou Research Center 


\section{Deffan et al. J. Appl. Biosci. 2015 Effect of conservation methods on the mineral contents of some maize varieties (Zea mays L.) produced in Côte d'Ivoire}

in Côte d'Ivoire. For each variety, $15 \mathrm{~kg}$ of maize grains were collected in bags, $15 \mathrm{~kg}$ in the granaries and $15 \mathrm{~kg}$ of maize cobs were stored in the attics. From each enclosure, $500 \mathrm{~g}$ of maize were sampled every 30 days during 120 days. Then $100 \mathrm{~g}$ of each sub-sample were thinly crushed using a GLEN CRESTON type chopper with $1 \mathrm{~mm}$ sieve diameter for obtaining fine meal for analysis purpose. The different flours obtained were placed in plastic boxes hermetically closed and kept in a cold room $\left(6^{\circ} \mathrm{C}\right)$.

Determination of mineral content: $5 \mathrm{~g}$ of maize flour were incinerated in an oven at $550^{\circ} \mathrm{C}$ for $24 \mathrm{~h}$ (AOAC, 1990). The qualitative and quantitative mineral determination was done using a scanning electron

\section{RESULTS}

Ash content of maize varieties during preservation: The variation of local maize varieties ash content is different in the three preserving materials after four months (table 2). For 'Violet de Katiola", a significant ash rate increase $(1.62 \% \mathrm{MS})$ was observed after 30 days of preservation in the attic and the bag (with respectively $2.28 \%$ and $2.41 \% \mathrm{MS}$ ). Any variation was observed in the Granary. Concerning AC 176 variety, ash content significantly increased (from $1.40 \% \mathrm{MS}$ to $1.75 \% \mathrm{MS}$ ) after 30 days of preservation in the attic and after 60 days microscope (SEM) (Supra 40 VP Zeiss 2008, Zurich, Switzerland) at variable pressure, enabling the analysis of non-metallic samples with a micro-analyzer (INCA of OXFORD instruments, Zurich, Switzerland).

Statistical analysis: All analyses were carried out in triplicates. Results were expressed by means $\pm S D$. Statistical significance was established using one-way analysis of variance (ANOVA) models to estimate the effect of storing time on the mineral content levels. Means were separated according to Duncan's multiple range analysis $(p<0.05)$, with the help of the STATISTICA 7.1 software.

in the bag (from $1.40 \% \mathrm{MS}$ to $2.39 \% \mathrm{MS}$ ), but any variation was observed in the granary. Thus, local varieties ash content is best preserved in the granary. For improved varieties, (table 3 ), the rate of ash in the Obatanpa variety significantly decreased after 60 days in the granary (from $1.68 \% \mathrm{MS}$ to $1.25 \% \mathrm{MS}$ ), while in the attic this rate significantly increased during the same time $(2.15 \% \mathrm{MS})$ and in the bag, the rate increased significantly after 60 days $(2.22 \% \mathrm{MS})$ and 90 days $(2.23$ $\% \mathrm{MS})$..

Table 2: Variation of local maize varieties ash content during storage

\begin{tabular}{|c|c|c|c|c|}
\hline \multicolumn{5}{|c|}{ Rate of ash (\%MS) } \\
\hline \multirow{2}{*}{ Varieties } & Period (day) & \multicolumn{3}{|c|}{ Preservation methods } \\
\hline & \multirow{6}{*}{$\begin{array}{l}\text { Day } 0 \\
30 \\
60 \\
90 \\
120\end{array}$} & Granary & Attic & Bag \\
\hline \multirow{5}{*}{ VK } & & $1.62 \pm 0.10^{a}$ & $1.62 \pm 0.10^{a}$ & $1.62 \pm 0.10^{a}$ \\
\hline & & $1.58 \pm 0.22 \mathrm{aA}$ & $2.28 \pm 0.22 \mathrm{cB}$ & $2.41 \pm 0.06^{c B}$ \\
\hline & & $1.68 \pm 0.11 \mathrm{aA}$ & $1.95 \pm 0.17 \mathrm{bB}$ & $1.93 \pm 0.15 \mathrm{bB}$ \\
\hline & & $1.81 \pm 0.10 \mathrm{aA}$ & $1.85 \pm 0.10 \mathrm{bA}$ & $2.02 \pm 0.04 \mathrm{bB}$ \\
\hline & & $1.75 \pm 0.35$ a АB & $1.88 \pm 0.00 \mathrm{bA}$ & $1.96 \pm 0.02 \mathrm{bB}$ \\
\hline \multirow{5}{*}{ AC 176} & \multirow{5}{*}{$\begin{array}{l}\text { Day } 0 \\
30 \\
60 \\
90 \\
120\end{array}$} & $1.40 \pm 0.10^{a}$ & $1.40 \pm 0.10^{a}$ & $1.40 \pm 0.10^{a}$ \\
\hline & & $1.46 \pm 0.08 \mathrm{aA}$ & $1.75 \pm 0.48^{\mathrm{bB}}$ & $1.38 \pm 0.06$ a A \\
\hline & & $1.45 \pm 0.11 \mathrm{aA}$ & $2.06 \pm 0.38 \mathrm{cB}$ & $2.39 \pm 0.29 \mathrm{cB}$ \\
\hline & & $1.48 \pm 0.11 \mathrm{aA}$ & $1.76 \pm 0.13$ ьв & $1.99 \pm 0.14 \mathrm{bB}$ \\
\hline & & $1.38 \pm 0.23 \mathrm{aA}$ & $1.57 \pm 0.12 \mathrm{aA}$ & $1.79 \pm 0.03 \mathrm{bA}$ \\
\hline
\end{tabular}

Note: Within a column, values with the same superscript small letters are not significantly different at $P>0.05$. Within a line values with the same superscript capital letters are not significantly different at $P>0,05$.

Concerning the MDJ variety, ash rate significantly decreased after 60 days in the Granary and the bag (from $1.30 \% \mathrm{MS}$ to $1.00 \%$ and $1.27 \% \mathrm{MS}$ respectively), and significantly increased in the Attic (2.21\% MS). EV8728 variety ash rate significantly decreased after 30 days in the Granary, the Attic and bag (from $1.74 \%$ MS to $1.24 \%$, $1.23 \%$ and $1.28 \%$ MS respectively). GMRP18 variety ash rate decreased significantly after 30 days in the Granary, the Attic and bag (from $1.72 \%$ MS to $1.26 \%, 1.25 \%$ and $1.24 \%$ MS respectively). Concerning ACr97comp1w 


\section{Deffan et al. J. Appl. Biosci. 2015 Effect of conservation methods on the mineral contents of some maize varieties (Zea mays L.) produced in Côte d'Ivoire}

variety, ash content significantly increased after 30 to 60 days in the Granary and the Attic (from $1.51 \%$ MS to 2.05 to $2.10 \% \mathrm{MS}$ and from $1.51 \% \mathrm{MS} 2.04$ to $2.15 \% \mathrm{MS}$ respectively). In the bag, this rate significantly decreased between 60 and 90 days (from $2.17 \%$ MS to $1.65 \%$ MS). Concerning ACr97comp1wsynth variety, ash rate significantly increased after 60 days in the Granary (from
$1.41 \% \mathrm{MS}$ to $2.75 \% \mathrm{MS}$ ), increased after 30 days in the Attic $(1.62 \% \mathrm{MS})$. In the bag, the ash rate increase was regular from the beginning to the end of the storage. We can deduce that in the improved varieties, ash content was not preserved in the granary, the attic and the jute bag

Table 3: Variation of improved maize varieties ash content during storage

\begin{tabular}{|c|c|c|c|c|}
\hline \multicolumn{5}{|c|}{ Rate of ash (\%MS) } \\
\hline Varieties & \begin{tabular}{|l}
$\begin{array}{l}\text { Periods } \\
\text { (day) }\end{array}$ \\
\end{tabular} & \multicolumn{3}{|c|}{ Preservation methods } \\
\hline \multirow{6}{*}{ Obatanpa } & \multirow{6}{*}{\begin{tabular}{|l} 
Day 0 \\
30 \\
60 \\
90 \\
120 \\
\end{tabular}} & Granary & Attic & Bag \\
\hline & & $1.68 \pm 0.21^{b}$ & $1.68 \pm 0.21^{\mathrm{a}}$ & $1.68 \pm 0.21^{a}$ \\
\hline & & $1.67 \pm 0.12^{\mathrm{bA}}$ & $1.71 \pm 0.11 \mathrm{aA}$ & $1.66 \pm 0.08 \mathrm{aA}^{\mathrm{A}}$ \\
\hline & & $1.25 \pm 0.24$ a A & $2.15 \pm 0.11 \mathrm{bB}$ & $2.22 \pm 0.11 \mathrm{bB}$ \\
\hline & & $1.69 \pm 0.11 \mathrm{bA}$ & $1.73 \pm 0.11$ a A & $2.23 \pm 0.50 \mathrm{bB}$ \\
\hline & & $1.62 \pm 0.03 \mathrm{~b} \mathrm{~A}$ & $1.56 \pm 0.12 \mathrm{aA}$ & $1.66 \pm 0.11 \mathrm{aA}$ \\
\hline \multirow{5}{*}{ MDJ } & \multirow{5}{*}{$\begin{array}{l}\text { Day } 0 \\
30 \\
60 \\
90 \\
120\end{array}$} & $1.30 \pm 0.21 \mathrm{~b}$ & $1.30 \pm 0.21 \mathrm{a}$ & $1.30 \pm 0.21^{\mathrm{a}}$ \\
\hline & & $1.22 \pm 0.11 \mathrm{bA}$ & $1.21 \pm 0.12 \mathrm{aA}$ & $1.27 \pm 0.06 \mathrm{aA}^{\mathrm{A}}$ \\
\hline & & $1.00 \pm 0.11 \mathrm{aA}$ & $2.21 \pm 0.05^{c B}$ & $2.25 \pm 0.07 \mathrm{cB}$ \\
\hline & & $1.36 \pm 0.00 \mathrm{bA}$ & $1.35 \pm 0.10 \mathrm{aA}$ & $1.63 \pm 0.06 \mathrm{bB}$ \\
\hline & & $1.39 \pm 0.01 \mathrm{bA}$ & $1.68 \pm 0.00 \mathrm{bB}$ & $1.85 \pm 0.10 \mathrm{bB}$ \\
\hline \multirow{5}{*}{ EV8728 } & \multirow{5}{*}{\begin{tabular}{|l} 
Day 0 \\
30 \\
60 \\
90 \\
120
\end{tabular}} & $1.74 \pm 0.44 \mathrm{bc}$ & $1.74 \pm 0.44 b$ & $1.74 \pm 0.44^{b}$ \\
\hline & & $1.24 \pm 0.19$ a A & $1.23 \pm 0.19 \mathrm{aA}$ & $1.28 \pm 0.21 \mathrm{aA}$ \\
\hline & & $1.43 \pm 0.09 a b \mathrm{~A}$ & $1.92 \pm 0.11 \mathrm{CB}$ & $2.03 \pm 0.05^{\mathrm{cB}}$ \\
\hline & & $1.58 \pm 0.00 \mathrm{~b} \mathrm{~A}$ & $1.61 \pm 0.00 \mathrm{bA}$ & $1.87 \pm 0.00 \mathrm{bcB}$ \\
\hline & & $1.26 \pm 0.11 \mathrm{a} \mathrm{A}$ & $1.55 \pm 0.12 \mathrm{bB}$ & $1.66 \pm 0.11 \mathrm{bB}$ \\
\hline \multirow{5}{*}{ GMRP18 } & \multirow{5}{*}{$\begin{array}{l}\text { Day } 0 \\
30 \\
60 \\
90 \\
120\end{array}$} & $1.72 \pm 0.44^{c}$ & $1.72 \pm 0.44 \mathrm{~b}$ & $1.72 \pm 0.44^{b}$ \\
\hline & & $1.26 \pm 0.08 \mathrm{aA}$ & $1.25 \pm 0.11 \mathrm{aA}$ & $1.24 \pm 0.09 \mathrm{aA}$ \\
\hline & & $2.10 \pm 0.11 \mathrm{cA}$ & $2.39 \pm 0.11 \mathrm{cA}$ & $2.45 \pm 0.12 \mathrm{cA}$ \\
\hline & & $1.92 \pm 0.11 \mathrm{cA}$ & $1.93 \pm 0.11 \mathrm{bA}$ & $2.41 \pm 0.48 \mathrm{bcB}$ \\
\hline & & $1.63 \pm 0.00 \mathrm{bA}$ & $2.06 \pm 0.12$ b в & $2.17 \pm 0.05$ в в \\
\hline \multirow{5}{*}{ Acr 97comp1w } & \multirow{5}{*}{$\begin{array}{l}\text { Day } 0 \\
30 \\
60 \\
90 \\
120\end{array}$} & $1.51 \pm 0.01^{b}$ & $1.51 \pm 0.01 \mathrm{a}$ & $1.51 \pm 0.01^{b}$ \\
\hline & & $2.05 \pm 0.25 \mathrm{cA}$ & $2.04 \pm 0.23 \mathrm{~b} \mathrm{~A}$ & $2.03 \pm 0.20 \mathrm{bA}$ \\
\hline & & $2.10 \pm 0.11 \mathrm{cA}$ & $2.15 \pm 0.11 \mathrm{~b} \mathrm{~A}$ & $2.17 \pm 0.14 \mathrm{bA}$ \\
\hline & & $1.47 \pm 0.11 \mathrm{ab} \mathrm{A}$ & $1.48 \pm 0.11$ a A & $1.65 \pm 0.10 \mathrm{aA}$ \\
\hline & & $1.28 \pm 0.12$ a A & $1.67 \pm 0.00 \mathrm{aB}$ & $2.04 \pm 0.01 b c$ \\
\hline \multirow{5}{*}{$\begin{array}{l}\mathrm{ACr} \\
\text { 97comp1wsynth }\end{array}$} & \multirow{5}{*}{$\begin{array}{l}\text { Day } 0 \\
30 \\
60 \\
90 \\
120 \\
\end{array}$} & $1.41 \pm 0.11^{b}$ & $1.41 \pm 0.11^{\mathrm{a}}$ & $1.41 \pm 0.11^{\mathrm{a}}$ \\
\hline & & $1.58 \pm 0.10^{b A}$ & $1.62 \pm 0.06^{b A}$ & $1.62 \pm 0.07 \mathrm{bA}$ \\
\hline & & $2.75 \pm 0.11 \mathrm{cA}$ & $1.38 \pm 0.00 \mathrm{aB}$ & $1.69 \pm 0.10^{b A}$ \\
\hline & & $1.36 \pm 0.00 \mathrm{ab} \mathrm{A}$ & $2.67 \pm 0.00^{c B}$ & $2.69 \pm 0.10 \mathrm{CB}$ \\
\hline & & $1.16 \pm 0.00 \mathrm{aA}$ & $2.05 \pm 0.12 c B$ & $2.13 \pm 0.05 \mathrm{cB}$ \\
\hline
\end{tabular}

Note: Within a column, values with the same superscript small letters are not significantly different at $P>005$. Within a line values with the same superscript capital letters are not significantly different at $P>0.05$.

Mineral content of maize varieties during the magnesium $(\mathrm{Mg})$ and calcium $(\mathrm{Ca})$ were the four main preservation: Potassium $(K)$, phosphorus $(P)$, elements identified in all varieties (Figure 1, 2, 3, 4, 5, 6, 7 


\section{Deffan et al. J. Appl. Biosci. 2015 Effect of conservation methods on the mineral contents of some maize varieties (Zea mays L.) produced in Côte d'Ivoire}

and 8 ). The variation of the mineral contents in the maize varieties was measured during the storage. Concerning "Violet de Katiola" preserved in the granary, only $\mathrm{Ca}$ and $\mathrm{Mg}$ contents were significantly maintained after 30 days and 120 days respectively (Figure 1 ). $\mathrm{P}$ and $\mathrm{K}$ contents were not maintained but increased significantly after the first 30 days (values increased from $202.33 \mathrm{mg}$ to 213.5 $\mathrm{mg}$ for $\mathrm{P}$ and from $271.17 \mathrm{mg}$ to $299 \mathrm{mg}$ for $\mathrm{K}$ ). In the Attic, only Mg content remained significantly constant after 120 days (values oscillated between 63.5 and 69.93 $\mathrm{mg}$ ), but after only 30 days of preservation, $\mathrm{Ca}, \mathrm{P}$ and $\mathrm{K}$ rates increased from $8.65 \mathrm{mg}$ to $16.67 \mathrm{mg}, 202.33 \mathrm{mg}$ to $220.47 \mathrm{mg}$ and $271.17 \mathrm{mg}$ to $294 \mathrm{mg}$ respectively. In the bag, $\mathrm{Mg}$ and $\mathrm{K}$ amount did not change throughout the term of preservation time and $P$ content was maintained only for 30 days. Ca content was not maintained because significantly increased during the storage. We can deduce that the granary and the bag were more appropriate for the maintenance of the greater part of "Violet de Katiola" mineral constituents. $\mathrm{Ca}$ and $\mathrm{Mg}$ contents in AC176 preserved in granary did not significantly vary after 30 days and 120 days of storage (rates varied around $14 \mathrm{mg}$ for Ca after 30 days and $59.5 \mathrm{mg}$ for $\mathrm{Mg}$ after 120 days). On the other hand, $\mathrm{P}$ content increased and $\mathrm{K}$ significantly decreased after 30 days of storage (Figure 2). $\mathrm{P}, \mathrm{K}$ and $\mathrm{Mg}$ contents in $\mathrm{AC} 176$ preserved in attic remained constant after 60 days (for $P$ ), 90 days (for $K$ ) and 120 days (for $\mathrm{Mg}$ ), but the $\mathrm{Ca}$ rate significantly decreased after 30 days of preservation. In the jute bag, Ca rate was constant after 60 days; $M g$ content remained constant during the storage, $\mathrm{P}$ content increased and $\mathrm{K}$ content significantly decreased after 30 days. We can deduce that the minerals of $\mathrm{AC} 176$ variety were best preserved in the attic except for $\mathrm{Mg}$, which was well preserved in the three storage devices. In the granary, $\mathrm{Ca}$ rate in Obatanpa (a protein-rich variety) was stable during 120 days of storage (values ranging between $14 \mathrm{mg}$ and $24 \mathrm{mg}$ ), but $\mathrm{P}$ and $\mathrm{Mg}$ rates significantly increased over time and $\mathrm{K}$ content, significantly decreased over time (Figure 3). In the attic, $\mathrm{Ca}$ and $\mathrm{P}$ rates remained significantly constant after 30 days of preservation, $\mathrm{Mg}$ content increased significantly during the first 30 days of preservation and $\mathrm{K}$ content decreased during 90 days, then increased during the next 30 days. In the bag, only $P$ content remained stable after 30 days of storage, but $\mathrm{Ca}$ and $\mathrm{Mg}$ rates significantly increased after the same time; $\mathrm{K}$ content decreased during 90 days of preservation, then increased during the next 30 days. In the granary, $\mathrm{Ca}$ and $\mathrm{Mg}$ contents in the MDJ variety did not vary after 30 days for $\mathrm{Ca}$ and after 120 days for the Mg; however, $\mathrm{P}$ content significantly increased, and $\mathrm{K}$ content significantly decreased after 30 days of storage (Figure 4). In the attic, $\mathrm{P}$ and $\mathrm{Mg}$ levels were significantly constant after 30 days for $\mathrm{P}, 120$ days for $\mathrm{Mg}$; Ca content decreased after 30 days of preservation and $\mathrm{K}$ content significantly increased after 30 days. In the bag, $\mathrm{Ca}, \mathrm{P}$ and $\mathrm{Mg}$ rates were constant after 60 days for $P$, after 90 days for $\mathrm{Ca}$ and 120 days for Mg. It appeared that the bag was more appropriate for the preservation of the greater part of MDJ minerals.

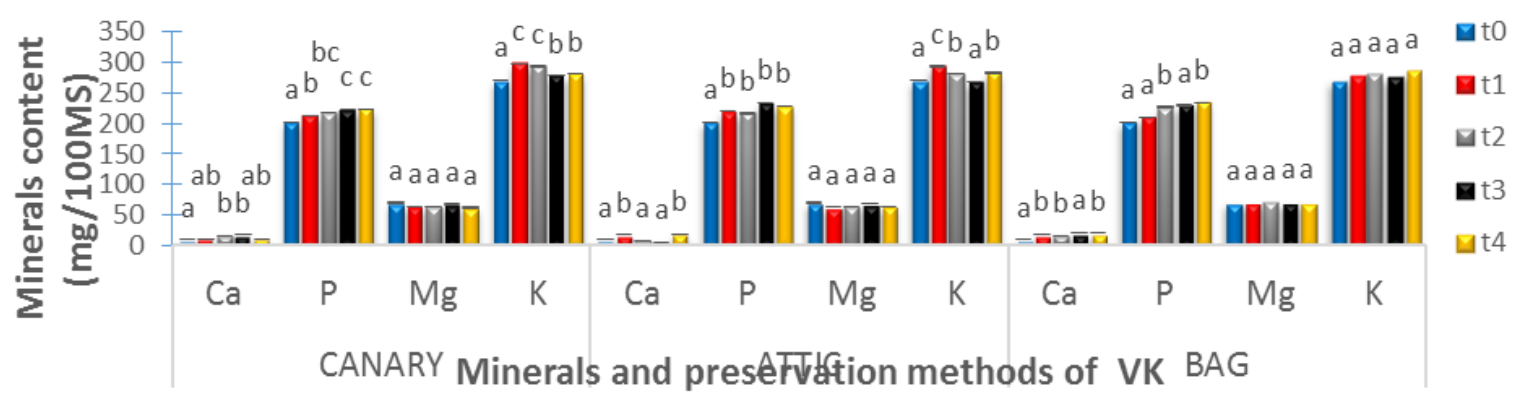

Figure 1: Variation of Violet de Katiola mineral contents according to preservation device. 


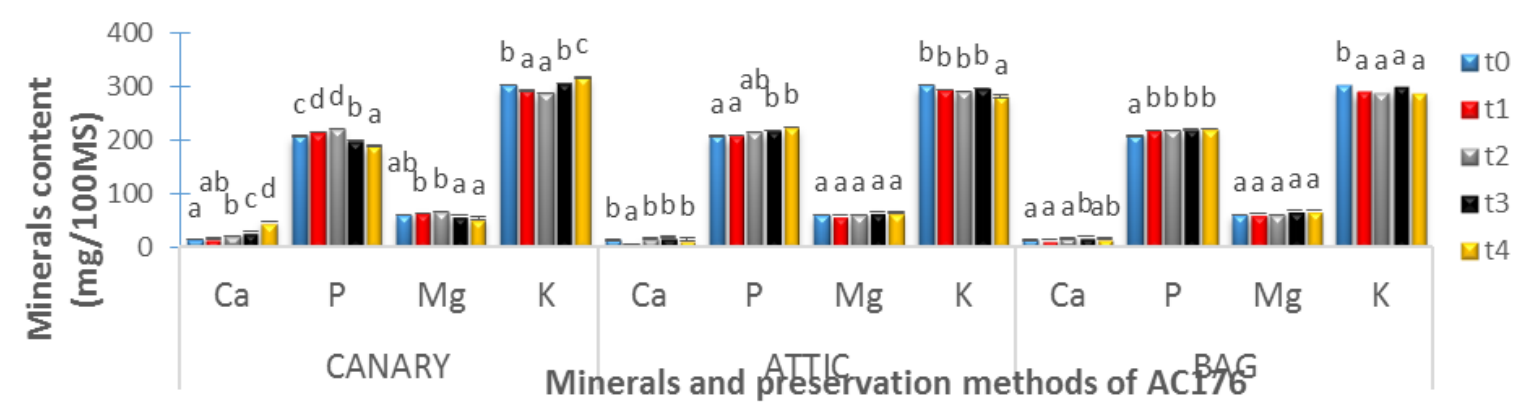

Figure 2: Variation of AC176 mineral contents according to preservation device

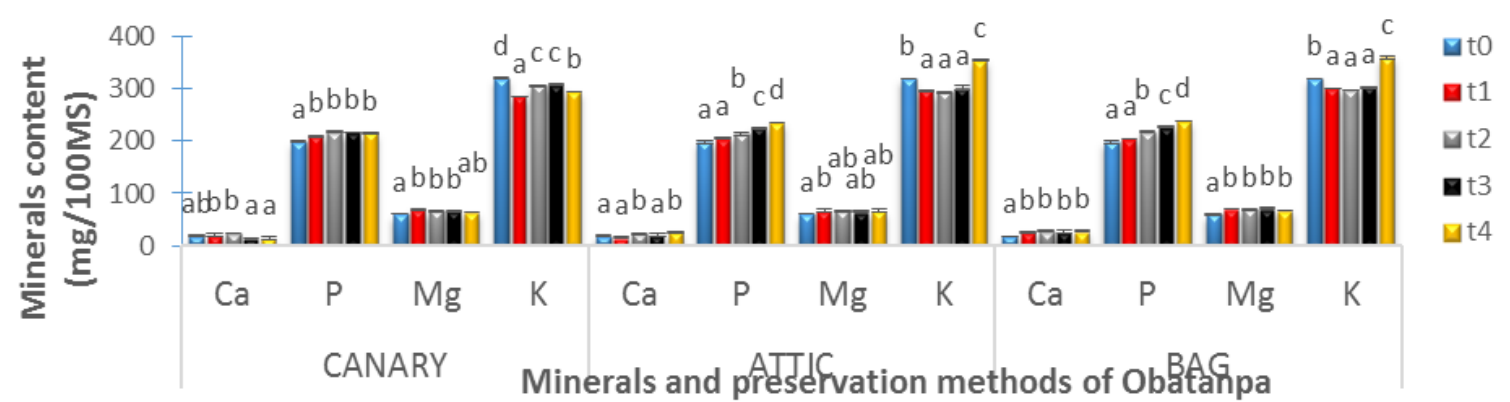

Figure 3: Variation of Obatanpa mineral contents according to preservation device

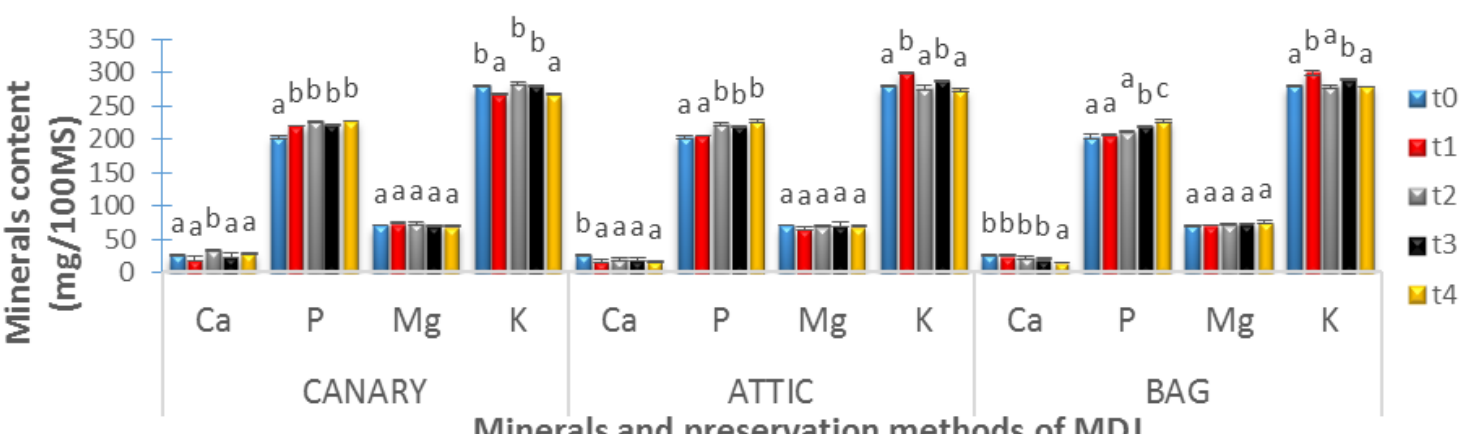

Minerals and preservation methods of MDJ

Figure 4: Variation of MDJ mineral contents according to preservation device

Note: histograms with the same letter for each of the minerals are not significantly different at $P>0.05$. T0: initial content; T1: content after 30 days of preservation; T2: content after 60 days of preservation; T3: content after 90 days of preservation; T4: content after 120 days of preservation.

In the granary, $\mathrm{Mg}$ and $\mathrm{K}$ contents in EV8728 variety were significantly constant after 120 days for Mg and only 60 days for $\mathrm{K}$ (Figure 5). However, $\mathrm{P}$ and $\mathrm{Ca}$ contents significantly increased during the first 30 days of conservation. In the attic, $\mathrm{Ca}$ and $\mathrm{P}$ contents remained significantly constant after the first 30 days and $\mathrm{Mg}$ content after 120 days. However, $\mathrm{K}$ content increased after the first 30 days of preservation. In the bag, $\mathrm{Ca}$ and $\mathrm{Mg}$ rates remained constant during all the storage time but $P$ content was maintained only during the first 30 days. It appeared that the attic and the bag were more appropriate for the conservation of EV8728 mineral constituents. In the granary, $\mathrm{Ca}$ and Mg rates in GMRP18 variety remained significantly constant during all the storage time but $\mathrm{P}$ content increased and $\mathrm{K}$ content decreased after 30 days of conservation (Figure 6 ). In the attic, the results were similar to those in the granary. It appears therefore that the mineral contents in GMRP18 varied in the same way in the three preservation devices. In the granary, $\mathrm{Ca}$ and $\mathrm{Mg}$ rates in $\mathrm{ACr} 97$ comp $1 \mathrm{w}$ variety 


\section{Deffan et al. J. Appl. Biosci. 2015 Effect of conservation methods on the mineral contents of some maize varieties (Zea mays L.) produced in Côte d'Ivoire}

remained significantly unchanged during the storage, but $\mathrm{P}$ content increased and $\mathrm{K}$ content decreased after 30 days (Figure 7). In the attic, $\mathrm{Ca}$ and $\mathrm{Mg}$ rates were stable during 120 days and $P$ content after 90 days but $K$ content decreased after 30 days. In the bag, $\mathrm{Mg}, \mathrm{Ca}$ and $P$ concentrations were significantly constant respectively after 120, 60 and 30 days of storage. It therefore appeared that in $\mathrm{ACr} 97$ comp1w, $\mathrm{Ca}$ and $\mathrm{Mg}$ contents were best preserved in the three conservation devices. In
ACr97comp1wsynth variety, $\mathrm{Ca}, \mathrm{Mg}$ and $\mathrm{K}$ contents were significantly stable for all the preservation time (120 days) and $P$ content was maintained during only 30 days of storage (Figure 8). In the attic, the results were similar to those in the granary. In the bag, the results were similar to those in the attic. We can deduce that mineral contents in ACr97comp1wsynth variety were preserved in the three conservation modes.

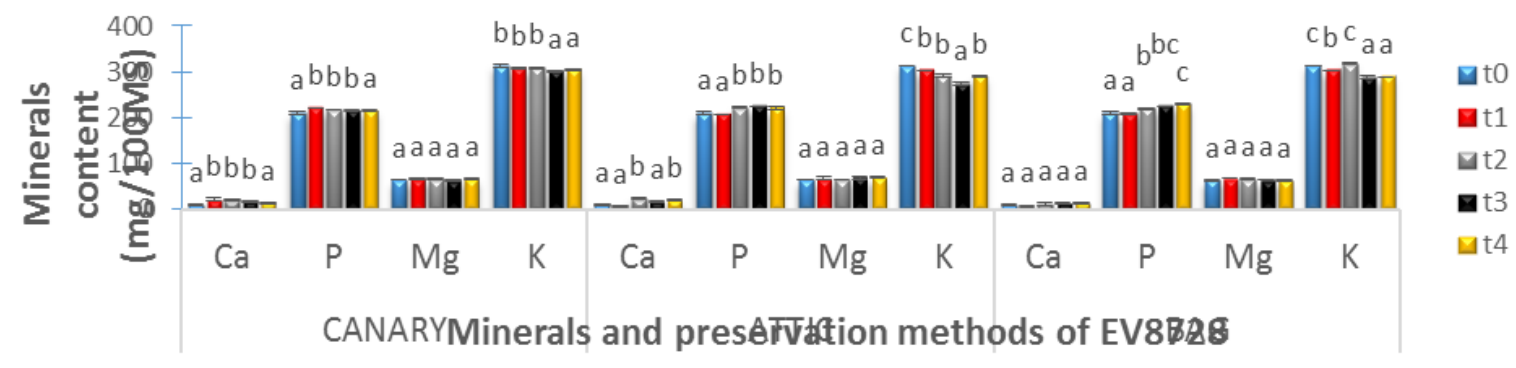

Figure 5: Variation of EV8728 mineral contents according to preservation device.

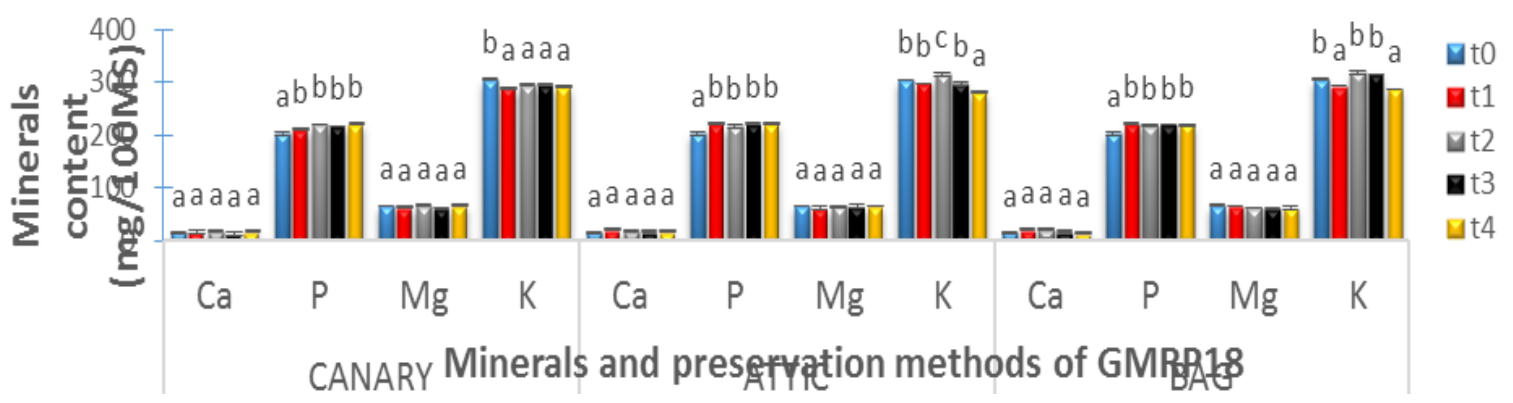

Figure 6: Variation of GMRP18 mineral contents according to preservation device

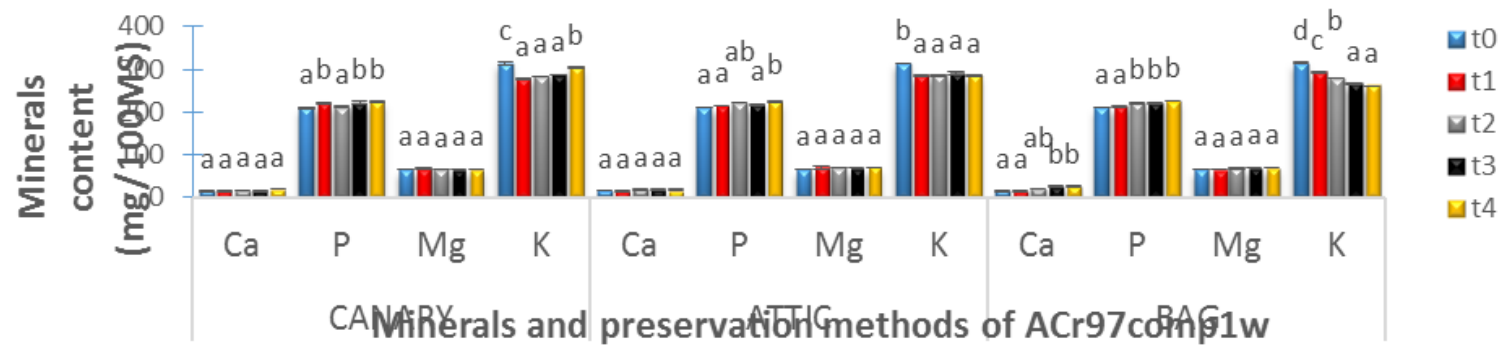

Figure 7: Variation of ACr97TZLcomp1w mineral contents according to preservation device 


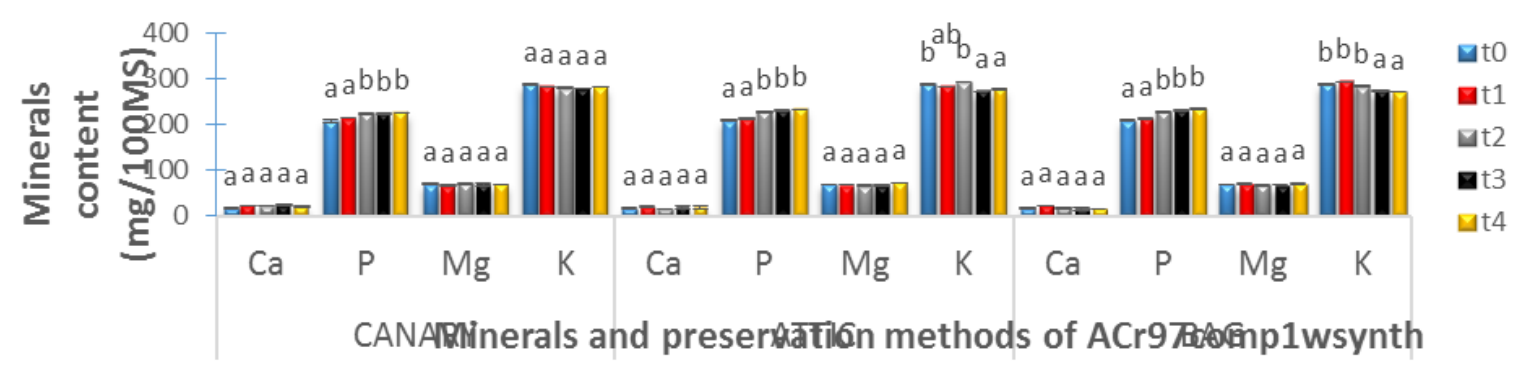

Figure 8: Variation of ACr97TZLcomp1wsynth mineral contents according to preservation device

Note: histograms with the same letter for each of the minerals are not significantly different at $P>0.05$. T0: initial content; T1: content after 30 days of preservation; T2: content after 60 days of preservation; T3: content after 90 days of preservation; T4: content after 120 days of preservation

\section{DISCUSSION}

The duration and the preservation method are some important factors acting on the quantity and the nutritional quality of cereals (O'Quinn et al., 2000). To get a general idea on the nutritional quality and especially on mineral elements of maize grains during preservation, ash content was determined. Ash rates recorded in our maize varieties during preservation ranged between 1.20 and $2.93 \%$. These results are similar to those of wheat that lie between 1.7 and 2.1\% (MSDA, 1994). Maize varieties ash content decreased or increased depending on time, preservation device and variety. According to Will and Fourre (1998), this variability of ash content is influenced by genetic, climatic, agronomic and technological factors. Analysis of the mineral constituents of maize varieties during preservation has highlighted that $\mathrm{Ca}, \mathrm{P}, \mathrm{K}$ and $\mathrm{Mg}$ were the four important minerals. All the concentrations of these minerals were lower than those indicated by FAO (1993), which were respectively $48.3 \mathrm{mg} / 100 \mathrm{G} ; 299.6$ $\mathrm{mg} / 100 \mathrm{~g} ; 324.8 \mathrm{mg} / 100 \mathrm{~g}$ and $107.9 \mathrm{mg} / 100 \mathrm{~g}$ in maize grains. The variation of mineral rates depends on maize variety and storage mode. $\mathrm{Mg}$ and $\mathrm{Ca}$ rates did not change in almost all varieties for respectively 120 and 30 days of preservation in the granary, the attic and the bag. However, $\mathrm{K}$ was best preserved in the bag (during 120 days) for violet de Katiola, in the attic (during 90 days) for AC176 variety, in the granary (during 60 days) for EV8728 variety and in the three preservation modes (between 60 et 120 days) for $\mathrm{ACr} 97$ comp 1 wsynth variety. $\mathrm{P}$ was best preserved in the attic (during 90 days) for ACr97comp1w variety. In fact, most of the variations observed during the storage, in particular the increase of ash content and therefore the mineral content can be explained by the decrease in some carbohydrate constituents because of respiration and mobilization of reserves at the harvest of maize varieties (Treche and Guion, 1980). The variations observed during the storage in the granary and the bags were more important than those recorded in the attic. It should be noted that our results were lower than those from the Swiss database of feed (Agroscope, 2008) and from France (I.N.R.A.; A.F.Z., 2004). These minerals are part of essential micronutrients, because contributing to the proper functioning of human organism through their involvement in the physiological and metabolic reactions. They need to be used in very small quantities in the diet to stimulate cell growth and metabolism (Oyewole and Asagbra, 2003). Calcium is involved in the formation of bones and teeth while magnesium is an important cofactor in many reactions of cellular metabolism (Soetan et al., 2010). Phosphorus is a mineral that is involved in the production of cellular energy and in the synthesis of phospholipids, nucleic acids and phosphoproteins, while potassium plays an important role in the regulation of cellular osmotic balance (Murray et al., 2000). Our local and improved maize varieties would be suitable to feed 4 to 6 years old children whose magnesium requirements are estimated at $76 \mathrm{mg} / \mathrm{d}$ (FAO, 2004). In addition, the mineral composition of the maize varieties studied revealed the absence of heavy metals such as lead and cadmium, which have a toxic effect by increasing oxidative stress and adversely affecting the reproduction function (Soetan et al., 2010). 


\section{Deffan et al. J. Appl. Biosci. 2015 Effect of conservation methods on the mineral contents of some maize varieties (Zea mays L.) produced in Côte d'Ivoire}

\section{CONCLUSION}

This study was implemented to assess the variation of mineral constituents of maize varieties during preservation. Magnesium and calcium were quantitatively preserved in almost all varieties for respectively 120 and 30 days of storage in the granary, the attic and the bag. However, potassium was best preserved in the bag (for

120 days) for "violet de Katiola", in attic (90 days) for AC176 variety, in the granary (for 60 days) for EV8728 variety and the three preservation modes (between 60 et 120 days) for $\mathrm{ACr} 97$ comp 1 wsynth variety. Phosphorus was best preserved in the attic (90 days) for the ACr97comp1w variety.

\section{ACKNOWLEDGEMENTS}

The authors wish to thank the Centre National de Recherché Agronomique (CNRA) for the financial and technical supports of the study.

\section{REFERENCES}

Agroscope, 2008. Swiss database of pet food.http://www.Agroscope.admin.ch/Praxis/002 15/00801/index.html?lang=fr (accessed 20. 01. 2010)

Akanvou L., Akanvou R., Anguété K. et Diarrassouba L., 2007. Well cultivate maize in Ivory Coast. Technical specifications for the CNRA. Abidjan, Ivory Coast. $4 \mathrm{p}$.

AOAC, 1980. Association of Official Analytical Chemical, Official methods of analysis. Washington D.C. USA. $14 \mathrm{p}$.

BIPEA, 1976. Compendium of methods of analysis of the European communities. $160 \mathrm{p}$.

FAO, 1993. Maize in human nutrition. Food and nutrition. Collection $n^{\circ} 25$. Ed FAO, Geneva, $119 \mathrm{p}$.

$F A O, 2004$. Vitamin and mineral requirements in human nutrition. FAO red, Geneva, 340 pp.

National Institute of Agronomic Research (INRA) and French Association of Animal Science, 2004. Tables of composition and nutritional value of the raw materials intended for farmed animals. (Sauvant, d., Pérez, J.M., Tran, g., eds). Paris, France.

IITA, 2012. Maize. IITA (International Institute of Tropical Agriculture), Research to nourish Africa, $7 \mathrm{p}$.

ITCF, 1989. Cereals and fodder Technical Institute: Practical Guide - Storage and preservation of grain on the farm.

ITCF, 1996. Cereals and Fodder Technical Institute: practical Guide - cooling by ventilation.
MSDA, 1994. Cereals products of the milling industry, pre-mixes for oven, mixtures of flour, instant flours, $124 \mathrm{p}$.

Murray R.K., Granner D.K., Mayes P.A. and Rodwell V.W., 2000. Harper's Biochemistry, 25 th Edition, McGraw-Hill, Health Profession Division, USA, pp. 74-76.

Nuss T. E. and Tanumihardjo S. A., 2011. Quality Protein of Maize Africa: Closing the protein inadequacy gap in vulnerable populations. Adv. Nutr., 2: 217-224.

O'quinn P. R., Nelssen J. L., Goodband R. D., Knabe D. A.; Woodworth J. C., Tokach M. D., Lohrmann T. T., 2000. Nutritional value of a genetically improved high-lysine, high-oil maize for young pigs. J. Anim. Sci., 78, 2144-2149.

Oyewole O.B. and Asagbra Y., 2003. Improving traditional cassava processing for nutritional enhancement. International workshop, Ouagadougou, 23-28/11/2003, pp.369 - 382.

Schlegel P., Bracher A., and Hess H. D., 2009. Levels of minerals and trace elements of Swiss animal feed grains. DBF - GCM 2009. Swiss Journal of agriculture 41: 1-98.

Soetan K.O., Olaiya C.O. and Oyewole O.E., 2010. The importance of mineral elements for humans, domestic animal and plants: a review. Afr. J. Food Sci., 4: 200-222

Willm C. L. and Fourre N., 1998. The management of mill ash. Industry for cereals, 108. 